\title{
Pornography: A Plea for Law Reform
}

\author{
Susan Edwards *
}

\section{Introduction}

The growing effluvium of violent pornography in our midst, the inability of the Obscene Publications Act 1959 to effectively curb this incoming tide, the unwillingness of the Director of Public Prosecutions to prosecute the publishers of the books American Psycho and fuliette on the grounds that there is no reasonable prospect of conviction and the recent misplaced comments of Mr. Michael Jack of the Home Office that in matters relating to pornography we have nothing to fear from Europe, prompts me to look once again at the pornography debate and current legislation. ${ }^{1}$

This article proceeds, first, with an overview of the nature of the pornography flooding the domestic market; secondly, with a re-statement of the argument extended by those who see intervention of the law in this area as an anathema; thirdly, proceeds to examine the interpretation of the Obscene Publications Act 1959 in decided cases; and finally concludes with some modest proposals for reform.

\section{What is Pornography Today?}

What is considered pornographic today is indeed a very different species compared with what was considered pornographic a century ago or even what was deemed pornographic when the Williams Committee ${ }^{2}$ were deliberating in 1979. Moreover, we live in a very different ideological and political climate. For example, in the 19th century women had no locus standi, and no voice. Today, whether enforced or not we have legislation which criminalises racial hatred, ${ }^{3}$ prohibits indecent and racist chanting ${ }^{4}$ and allows women redress from discriminatory practices. ${ }^{5}$ We have a political climate in which it is said women have a voice. That voice is unanimously saying "no" to pornography.

* Senior Lecturer in Law, University of Buckingham.

1. S. Edwards, "A Plea for Censorship", N.L.J. (1991), 1478.

2. The Report of the Committee on Obscenity and Film Censorship, Cmnd. 7772 (1979).

3. Public Order Act 1986; Race Relations Act 1976.

4. Football (Offences) Act 1991, s. 3(i).

5. Sex Discrimination Act 1976. 


\section{i. Pornography as sex}

Pornography is considered by those who know only of 'soft pornography' to be exclusively a matter of sex, a matter of the erotic, of physical intimacy, of intercourse, in which both men and women play an equal part, and wherein the message being conveyed in the visual and written script is that she desires what is being done to her. And thus 'soft pornography' is a matter of freedom and is a matter of personal choice. In this we are misled and deliberately so. Many literary authorities have been similarly misled. For D. H. Lawrence: ${ }^{6}$

"Pornography to one man is the laughter of genius to another."

Montgomery Hyde wrote:?

"It is generally agreed that the essential characteristic of pornography is its sexuality."

This is the patriarchal illusion which is created. It is an illusion which those who make and profit from pornography must sustain if the institution is to survive. Sex hatred, sex abuse, sexual insult, must be formulated and contextualised within the arena of 'sex' in order that the exploitation, degradation and violence becomes obscured and when apparent must be understood as action the victim desires and has precipitated, thereby conflating her victimisation through her alleged complicity. Above all, pornography must be constituted outside the realm of reality and constructed instead as part of a fantasy world.

It is in the interest of the pornography profiteers that 'soft pornography' becomes the sample case on which we judge all pornography and what we understand pornography to be and around which we focus the debate of censorship and of freedom. Catherine MacKinnon, ${ }^{8}$ the American feminist lawyer and jurisprudent, identifies the way in which the parameters of the debate have been so cleverly articulated:

"Pornography has been considered a question of freedom to speak and depict the erotic, as against the obscene or violent."

\section{ii. Pornography as violence}

Pornography, whether portraying or depicting violence, is not about sex. It is about violence. The nature of violence is sexualised from the manner in which it is inflicted, in the nature of the pleasure it is designed to deliver to the observer, and

6. Cited in H. Montgomery Hyde, $A$ History of Pornography (1964), p. 10.

7. Ibid., p. 15.

8. C. A. Mackinnon, "Feminism, Marxism, Method and The State: An Agenda for Theory", (1982) Signs, vol. 7 no. 3, 515-544 at p. 531 . 
in the 'pleasure' it is falsely portrayed as delivering unto its victims. MacKinnon writes:" "In pornography, the violence is the sex."

\section{iii. Pornography as metaphor}

Pornography is also a powerful medium of communication and propaganda. It communicates sexual and violent scenarios, and sexualises the subordination of women. Andrea Dworkin, ${ }^{10}$ the feminist anti-pornographer, writes:

"In the subordination of women, inequality itself is sexualised: made into the experience of sexual pleasure, essential to sexual desire."

Pornography socialises men by conflating sex with violence, and by presenting the woman in the pornography as always wanting or secretly desiring what is happening to her, thereby reducing mens' responsibility for any of the harm inflicted, providing them with a vocabulary of excuses and justifications which render the element of exploitation and degradation non-existent by making the harm legitimate through her consent. " This is the message pornography communicates. Dworkin writes: ${ }^{12}$

"The insult pornography offers, invariably, to sex is accomplished in the active subordination of women: the creation of a sexual dynamic in which the putting-down of women, the suppression of women, and ultimately the brutalization of women, is what sex is taken to be."

There is not only the harm done to the person filmed in the pornography but the social harm perpetrated by the message which is being sold again and again, and again. This message educates men about sex and about their relation to women. This message is a lie. It is just as much a lie as was Freud' ${ }^{13}$ conclusion that women are narcissistic, masochistic and passive. It took the psychoanalyst, Karen Horney, ${ }^{14}$ to argue that those traits of womankind were the product of her social and politically situated self rather than any innate trait. Jacques Lacan ${ }^{15}$ proposed instead, by reversing the Freudian method that unconsciousness preceded language, that language preceded the unconscious. Adapting this Lacanian formulation as a metaphor for pornography, pornography in part precedes our

9. C. A. Mackinnon, "Not a Moral Issue", (1984) Yale Law and Policy Reviezw, vol. 11 no. 2, 321 -345 at p. 343.

10. A. Dworkin, “Against the Male Flood: Censorship, Pornography and Equality", (1985) Harvard Law fournal, vol. 8, 1-29 at p. 15.

11. See Laurie Taylor, "The significance and interpretation of replies to motivational questions: The case of sex offenders", (1972), Sociology no. 6, 12-29.

12. Dworkin, supra n. 10, at p. 9.

13. S. Freud, New Introductory Lectures (1974), p. 116.

14. K. Horney, Feminine Psychology (1967).

15. J. Lacan, The Four Fundamental Concepts of Psychoanalysis (1977). 
sexual relations, communicating to men a conflation of sex and violence and a pleasure in that conflation. Thes scenarios then form part of the socially structured fantasy world. Pornography creates and shapes mens' sexual fantasy and pornography provides the script for transforming that fantasy into reality.

\section{Censorship, Freedom and Harm}

Freedom for many is a philosophical idea, an abstraction without limitation, an ideal to be defended and upheld and an ideal which can become dislocated from the real world in which freedoms are concretised. As Voltaire ${ }^{16}$ is said to have declared:

"I disapprove of what you say, but I will defend to the death your right to say it."

I am sure that freedom of thought and conscience does not embrace freedom to abuse and debase women and children. Freedom is quintessentially about power. It is not something which can be given by one human being to another. Nor is it something which can be denied by one of another. The freedom being defended in pornography is specifically designed to uphold the power of those to subordinate, abuse and insult women. It is freedom to degrade and abuse which is the freedom which is so zealously defended and guarded. The freedom defended has nothing to do with the faceless notion of choice, which is the argument pornographers prefer to advance, that people should be free to read and see what they like. It has little to do with political and intellectual freedom. This is the fundamental confusion.

The principle expanded in the work of John Stuart Mill ${ }^{17}$ that,

"the only purpose for which power can be rightfully exercised over any member of a civilised community, against his will, is to prevent harm to others..."

has provided the philosophical and intellectual rationale for legal intervention and non-intervention. The late Lord Devlin's ${ }^{18}$ contribution to this philosophical question of law and morality was similarly premised on the view that the law should intervene only when there was demonstrable harm. Pornographers have dodged the loaded question of 'harm', intellectually orchestrating the debate around the neutrality of 'choice'.

Yet it would appear that current interpretation of obscenity legislation protects sexual violence exploitation and the 'harm'. Consider, for example, that if the

16. Commonly attributed to Voltaire though actually made up by C. S. Tallentyre. Drawn to my attention by my colleague, Owain Blackwell.

17. J. S. Mill, On Liberty, 13 (C. Shields ed. 1958).

18. P. Devlin, The Enforcement of Morals (1959). 
pornography is in the written word and if the material is considered so disgusting that it is deemed likely to repulse the ordinary man then it is protected through a decision not to prosecute. In England and Wales material which depicts sexual violence is prosecuted and convictions follow only if the material is likely to "deprave and corrupt", and is then considered 'obscene' within the meaning of the statute. In the U.S., the First Amendment ${ }^{19}$ similarly guards and defends the free speech of the pornographer and the free choice of the pornography consumer.

Those of us who make a plea for censorship are depicted as right wing, repressive, anti-sex and anti-homosexuality. Censorship in some of its guises smacks of state repression, police brutality and the silencing of political opposition. But what happens if the State are the police and the mob that howls at the door?

A pro-censorship position does not emerge out of a vacuum but is a specific response to a particular position. Censorship may be defining your limits while recognising my freedom. Censorship is as misunderstood in Western Europe as it is in the United States, writes Dworkin: ${ }^{20}$

"Censorship is deeply misunderstood in the United States, because the fairly spoiled, privileged, frivolous people who are the literate citizens of this country think that censorship is some foggy effort to suppress ideas. For them, censorship is not something in itself - an act of police power with discernible consequences to hunted people; instead, it is about something abstract - the suppressing or controlling of ideas."

Our freedom, that is the freedom of women, can only be recognised by limiting the choices of men.

Dworkin, ${ }^{21}$ in her evidence to the 1986 Meese Commission on pornography, educates in communicating to us the real nature and content and harm of pornography:

"My name is Andrea Dworkin. I am a citizen of the United States, and in this country where I live, every year millions of pictures are being made of women with our legs spread. We are called pussy, our genitals are tied up, they are pasted ... In this country where I live as a citizen, women are penetrated as animals and objects for public entertainment, women are urinated on and defecated on ... there is amputee pornography, a trade in

19. U.S. Constitution First Amendment. Congress shall make no law respecting an establishment of religion, or prohibiting the free exercise thereof; or abridging the freedom of speech or of the press; or the right of the people peaceably to assemble, and to petition the government for a redress of grievances.

20. Supra n. 10, at p. 3.

21. A. Dworkin, Personal Testimony to the Meese Commission 1986. Attorney-General Report on Pornography and Prostitution. Washington DC: US Department of Justice. 
women who have been maimed in that way, as if that is a sexual fetish for men. In this country where I live, there is a trade in racism as a form of sexual pleasure . . Black skin is presented as if it is a female genital, and all the violence and all the abuse and the humiliation that is in general directed against the female genitals is directed against the black skin of women."

There is not a description of American pornography whereby we can switch off and say "But this isn't the pornography here amongst us." This is a description of the very kind of pornography being sold and consumed in the U.K.. And the more the material reaches the far limits of human endurance and suffering, the more heightened becomes, not our sensitivities, but our tolerance level, and the more blunted our senses as the legal watershed rises, embraces and condones more and more explicit sex and, more worryingly, more and more insult, degradation and harm to women and children. It is just not clear any more that the law in its present form and the Crown Prosecution Service, predicting the response of juries in taking a decision not to prosecute, thereby usurping the jury, can ensure that this kind of material is censored.

The harm pornography does is specific. It is physical. It is ideological. In the production of pornography women and children suffer harm and abuse. The Meese Commission ${ }^{22}$ reached this conclusion:

"Substantial exposure to sexually violent materials as described here bears a causal relationship to anti-social acts of sexual violence and, for some sub-groups, possibly to unlawful acts of sexual violence."

The nature of the material itself demands that we take this matter out of the realms of choice. As Geoffrey Robertson ${ }^{23}$ has wisely remarked:

"... it is not always necessary to fight to the death for the right to debase others."

But how can we prevent this incoming tide? Has the law in this area been considered desirable, and how far has it been successful, if at all? And what is to be done about curbing this world trade in pornography?

\section{Engaging with the Law}

Whilst feminists are unanimous in saying 'no' to pornography, there is a deep schism over the role of law in its regulation. After all, the law has not earned itself any points in its protection, defence or equal treatment of women. And, there are plenty of deeply degrading images of women in popular cultural presentation 
which would be left untouched by any legislative intervention. We have seen over recent years ample evidence that the criminal law is woefully inadequate to deal with the incoming tide of violent and sadistic depictions of the sexual abuse, killing and torture of women and children currently found in the written word, in film and in video masquerading under the protective guise of 'art and literature' or else protected by a belief that the material is so terrible that the effect is one of shock rather than to deprave and corrupt. In short, criminal law in this area is a dead duck. The limitations of existing law, both here and in North America, have led to divers efforts to reform obscenity legislation and to develop forms of control other than those currently available within the criminal law. In the U.K., antipornography campaigners have sought to strengthen existing criminal law and at the time of writing a Private Members Bill ${ }^{24}$ is being discussed in the House to develop alternative legal controls by adapting existing sex discrimination legislation. Law reformers in other jurisdictions have sought a solution in the civil law. It has been a major consideration of the critique of law by contemporary feminists to transform law in a way which embraces womens' experiences and is therefore more consonant with their lives. ${ }^{25}$

The defects within the existing legislation are highlighted, yet again, by the recent decision of the Director of Public Prosecutions not to prosecute the publishers of de Sade's $f$ uliette, ${ }^{26}$ a vile book glorifying in the grossest way the torture and killing of children. Details of the book circulated to M.P.'s in July 1992 provided the galvanising force behind ministerial pressure for a revision of existing legislation. A similar decision to prosecute was taken in respect of Bret Ellis' American Psycho. ${ }^{27}$ The defects however lie not only within existing legislation but with cultural and Governmental apathy and a slavish adherence to the view that obscenity is a matter for private members and not for the Government.

Current legislative provision regulating obscenity straddle several statutes. Some statutes embrace a wide definition of obscenity as where material is considered (indecent and obscene) and applies to material imported which is not of EEC origin, and to material sent through the post. ${ }^{28}$ In 1959 the liberalisation of the law in England and Wales came with the introduction of the Obscene

24. Private Members Bill, currently being debated at the time of this article going to press.

25. See S. Edwards, Policing Domestic Violence (1989); Susan Edwards, Women on Trial (1984); Helen Kennedy, Eve Was Framed (1992); Martha Fineman and Nancy Sweet Thomadsen (eds.) At the Boundaries of Law (1991); Carol Smart, Feminism and the Power of Law (1989); Marianne Wesson, "Sex Lies and Videotape: The Pornographer as Censor", (1991) Washington Law Review, vol. 66, p. 913. 26. Marquis de Sade, 7 uliette, Arrow, London.

27. B. Ellis, American Psycho, Picador, London.

28. There are four separate rungs of procedure: first, legislation founded on the 'indecent and obscene' test, Customs Consolidation Act 1876, s. 42; the Post Office Act 1953, s. 11; secondly the common law relating to 'outraging public decency'; thirdly, offences relating to children, Protection of Children Act 1968; fourthly, the Obscenity legislation covered by the Obscene Publications Act 1959 and 1964 depends on the 'deprave and corrupt' test where the 1964 Act extends the legislation to possession of an obscene article. 
Publications Act, whilst in the United States liberalisation occurred within the U.S. Supreme Court decision in Roth v. United States, ${ }^{29}$ which held that the test for obscenity was "whether to the average person, applying contemporary community standards, the dominant theme of the material taken as a whole appeals to prurient interest."

In accordance with the Obscene Publications Act 1959:30

"... an article shall be deemed to be obscene if its effect or (where the article comprises two or more distinct items) the effect of any one of its items is, if taken as a whole, such as to tend to deprave and corrupt persons who are likely, having regard to all the relevant circumstances, to read, see or hear the matter contained or embodied in it."

By section 53 of the Criminal Law Act 1977 cinematographic exhibitions were brought into the ambit of the 1959 and 1964 Acts. ${ }^{31}$ And by 1990, the Broadcasting Act extended those provisions to television broadcasting. ${ }^{32}$

In an attempt to ensure uniformity in the application of the law throughout England and Wales, the Criminal Law Act 1977, section 53, provided that a prosecution under section 2(1) of the 1959 Act shall not be instituted except by or with the consent of the D.P.P.. The gradual seizing up of the law has led to a decrease in prosecutions and an increase in seizure and forfeiture.

In respect of seizure and forfeiture powers, under section 3 of the 1959 Act, the police may apply to a justice of the peace who may issue a warrant. The Criminal Justice Act 1977, section 25, provides that a warrant under section 3 may not be issued except on information laid on or on behalf of the D.P.P. or by a constable. These provisions followed the successful private forfeiture of the book Last Exit to Brooklyn by Hubert Selby. ${ }^{33}$ Since 1977 the use of seizure and forfeiture as a means of control has increased.

To expedite matters, given the number of items seized in each case, only a selection of sample material is accepted by the courts in evidence, following $R$. v. Crown Court at Snaresbrook. ${ }^{34}$ In this case, police selected sample items to be put forward as prosecution exhibits in each class. The appellant could, if he disagreed with this procedure, put forward two samples of his own. The appellant objected to the procedure and sought a declaration that this was wrong in law and sought mandamus. The key provisions are contained within the Obscene Publications Act. Under section 3 it is for the person objecting to the forfeiture to show why any

29. Roth v. United States 237 F 2d 796 (1957).

30. Obscene Publications Act (1959), s. 1(i).

31. Criminal Law Act 1971, s. 53; Obscene Publications Act 1964.

32. Broadcasting Act 1990, s. 162 (1).

33. Last Exit to Brooklyn: R. v. Calder and Boyars Ltd. [1968] 3 W.L.R. at p. 985d.

34. (1984) 79 Cr. App. R. 184. See also R. Stone, "Obscene Publications: the Problems Persist", [1984] Crim.L.R. 139. 
article should not be forfeited. Owing to the increasing difficulties of bringing successful prosecutions under section 2 of the Obscene Publications Act, forfeiture proceedings are preferred.

\section{i. Statutory interpretation}

For a successful prosecution under section 1 of the 1959 Act the prosecution must adduce that the article in question is obscene. This turns on whether the article is likely to "deprave and corrupt".

This requirement is a formula derived from the judgment of Cockburn $\mathrm{CJ}$ in $R$. v. Hicklin: ${ }^{35}$

". . . I think the test of obscenity is this, whether the tendency of the matter charged as obscenity is to deprave and corrupt those whose minds are open to such immoral influences, and in whose hands a publication of this sort may fall."

After the passage of the Obscene Publications Act 1959 through Parliament the "deprave and corrupt" test, although still undefined, became transformed from a matter which could largely be assumed if the material was deemed to be obscene, to one which could only be decided on by the effect of the material alone. Judges have had great difficulties in interpreting the true meaning and intention of parliament as embraced by this test, a phrase neither defined in statute nor in the case law. In the prosecution of Penguin publishers following their publication of D. H. Lawrence's Lady Chatterley's Lover in R. v. Penguin Books Ltd., Byrne J, ${ }^{36}$ applying a literal interpretation, told the jury:

". . . to deprave means to make morally bad, to pervert, to debase, or corrupt morally. The words 'to corrupt' mean to render morally unsound or rotten, to destroy the moral purity or chastity of, to pervert or ruin a good quality, to debase, to defile. ..."

Rogers J in the prosecution of the publishers of Hubert Selby Jr's The Last Exit to Brooklyn, in $R$. v. Calder and Boyars ${ }^{37}$ at the trial said:

“. . . those other vital words 'tend to deprave and corrupt' really mean just what they say. You have heard several efforts to define them. 'Tend' obviously means 'have a tendency to' or 'be inclined to'. 'Deprave' is defined in some dictionaries, as you have heard, as 'to make morally bad; to pervert or corrupt morally' and the word 'corrupt' has been defined as 'to render morally unsound or to pervert' ..." 
The Appeal Court found no fault with this direction, although allowed the appeal on other matters which related to the absence of the trial judge's proper direction respecting the 'public good' defence under section 4 .

Lord Wilberforce in Whyte ${ }^{38}$ found the phrase somewhat opaque and incapable of precise definition. Outlining the way in which the courts have dealt with the term, he said:

" '. . first, that no definition of 'deprave and corrupt' can be provided ( $R$. v. Calder and Boyars $L t d$.), though the words are meant to be strong and emphatic (see Knuller (Publishing, Printing and Promotions) Ltd. v. Director of Public Prosecutions per Lord Reid and Lord Simon of Glaisdale); secondly, that judges or juries must decide for or against a tendency to 'deprave and corrupt' as a question of fact and must do so without expert, i.e. psychological or sociological or medical, advice (R. v. Anderson)."

\section{ii. The effect of the material}

In arriving at a decision on obscenity a number of other considerations provide the context in which the material 'on trial'is to be judged. The article must be taken as a whole, that is the whole of the article, or book, or film must be considered in its context. However, the key matter or litmus test upon which all seems to turn is the likely effect of the material, the effect being defined as the likelihood or tendency that the article will deprave and corrupt. Aversion in the form of shock, loathing, revulsion or disgust does not qualify. On the contrary, the aversion potential or aversion effect has actually been used as a defence against an allegation of the likelihood that an article will deprave and corrupt and is therefore obscene, and also as a justification for the decision taken not to prosecute (discussed infra). In considering whether an article, when read as a whole, is obscene the court must take into account the effect on the likely audience. Having considered all these matters, an article is considered obscene for the purposes of the Act whether published for gain or not.

Judges in consideration of the 'effect' of such material have considered procurement of sexual fantasy, sexual arousal, leading morally astray, and criminal conduct as of relevance. Whilst physical illness, shock, distress and trauma are of course effects, they have been deemed of no relevance.

\section{a. Fantasy: the effect on the mind}

Given the ambiguity and uncertainty within the statute and lack of guidance in case law, courts are not sure what precise effect they are looking for, and the matter still remains indeterminate. Lord Wilberforce, ${ }^{39}$ whilst he queried in Whyte whether the effect might include imitative behaviour of a criminal kind, preferred the effect on the mind, as of central relevance and the primary target:

38. D.P.P. v. Whyte and Another [1972] 3 All E.R., at p. 19a.

39. Ibid., at pp. $18 \mathrm{j}$ and $20 \mathrm{c}$. 
"It is criminal conduct, general or sexual, that is feared (and we may note that the articles here treated of sadistic and violent behaviour) or departure from some code or morality, sexual or otherwise, and if so whose code, or from accepted or other beliefs, or the arousing of erotic desires 'normal' or 'abnormal', or as the justices have said 'fantasies in the mind . . ' influence on the mind is not merely within the law but is its primary target."

Lord Cross ${ }^{40}$ took this further into the realms of sexual arousal:

"It is, I think, reasonable to suppose ... that the products of such fantasies would in some cases be accompanied or followed by masturbation."

\section{b. Lead morally astray}

In Knuller v.D.P.P. ${ }^{41}$ the House of Lords held the word 'corrupt' to mean to "lead morally astray". Lord Simon said:

"Corrupt is a strong word. The Book of Common Prayer, following the Gospel, has "where rust and moth doth corrupt". The words "corrupt public morals" suggest conduct which a jury might find to be destructive to the very fabric of society."

\section{c. Imitation}

Judges in obscenity cases have not held "deprave and corrupt" to imply that the effect is one of imitative behaviour, although Rogers $\mathrm{J}^{42}$ in $R$. v. Calder and Boyars did say that to deprave was "to make people do wrong acts". In contrast, the criminal and family courts both here and in the U.S., when dealing with the sexual offender or sexual difficulties within marriage, are unequivocable about the real life effects of such material.

In $R$. v. Holloway, Lawton $\mathrm{LJ}^{43}$ said:

"In the course of our judicial experience we have dealt with cases of sexual offenders who have undoubtedly been incited to engage in criminal activity and criminal conduct by pornographic 'hard porn'. Those of us who have had to deal with matrimonial cases in the Family Division ... know that sometimes, matrimonial troubles are started by husbands who have been reading or seeing this kind of material and try to introduce in the matrimonial bed what they have read or seen. There is an evil in this kind of pornography. It is an evil which in our opinion has to be stopped."

40. Ibid., at p. $25 \mathrm{e}$.

41. Knuller (Publishing Printing and Promotions) Ltd. v. D.P.P. [1972] 2 All E.R. 898; [1973] A.C. 435, at p. $491 \mathrm{~B}$.

42. Hubert Selby, Last Exit to Brooklyn (1987 edition), at p. vii.

43. R. v. Holloway [1982] Crim.L.R. 467. 
U.S. case law shows that the courts and judges have been more robust and more convinced of a correlation. In Hoggard v. State: ${ }^{44}$

"We readily agree that the material was prejudicial. It could hardly be otherwise. But the argument that its probative value was lacking fades under scrutiny. This pornography and the offence being tried had a clear correlation: the pornography depicted deviate sexual acts of a forty two year old man and a six year old boy. More importantly, the pornography was used as the instrument by which the crime itself was solicited. The child was encouraged to look at the pictures and then encouraged to engage in it. The value of the evidence as proof of the crime is obvious."

In The State v. Herberg, 45 where the defendant had tortured his 14 year old female victim (including cutting off her fingers, gagging, rape, choking) in ways too horrific to detail here, and where books of sadism and torture were found in his possession, the Minnesota Supreme Court said:

"It appears that in committing these various acts, the defendant was giving life to some stories he had read in various pornographic books."

\section{iii. The effect on whom?}

One of the major problems of the legislation has been the formulation of the effect of the material on a specific audience. The test of obscenity is both relative and subjective, thus reversing the Hicklin formula, where once an article was deemed to be obscene the effect was presumed to follow. On the relative conception of obscenity, Lord Wilberforce ${ }^{46}$ in Whyte had this to say:

"Both the policy and the language of the Act have been plentifully criticised: the former we cannot question, and with the latter we must do our best. One thing at least is clear from this verbiage, that the Act has adopted a relative conception of obscenity ...

An article cannot be considered as obscene in itself: it can only be so in relation to its likely readers."

Kenneth Jones $\mathrm{J}^{47}$ reiterated this principle of relative obscenity in the case against the defendant company in respect of the film Last Tango in Paris: "there is no absolute test of obscenity ... the test of obscenity is a relative one."

44. Hoggard v. State 277 Ark 117, 640 S.W.2d (1982), Cert. denied, 460 U.S. 1022 (1983), cited in C. Mackinnon, "Pornography, Civil Rights, and Speech", (1985) Harvard Civil Rights - Civil Liberties Law Review Vol. 20, No. 1 Winter, at p. 46.

45. State v. Herberg 324 N.W.2d 346, 347 Minn. 1982 cited in Mackinnon, supra n. 44, at p. 50.

46. Whyte, supra n. 38 , at p. $17 \mathrm{c}$.

47. Last Tango in Paris: Attorney-General's Reference (No. 2 of 1975) [1976] 2 All E.R. 753, at p. 757g. 
Lord Pearson ${ }^{48}$ however took a very different view. The meaning of 'obscene' was neither relative nor subjective. The obscene can be discerned by something inherent and by the purpose or intention of the material in question:

"The question whether an article is obscene depends not only on its inherent character but also on what is being or is to be done with it."

When considering the likely effect of the material, case law has not treated all recipients with the same regard. A distinction is made between persons not exposed to such materials and therefore considered not depraved and corrupted, although potentially capable of being so depraved and corrupted, and persons considered already beyond the pale, well familiarised with such materials and thereby, some have argued, incapable of being depraved and corrupted. An extraordinary illogic!

So in a world of Bosch'ian people, the Obscene Publications Act would be dead and redundant since there would be no one to deprave or corrupt, the depraved and corrupted being already depraved and corrupt!

This was precisely the point persuasively argued by the defence in Whyte. The fact that young people were excluded from the bookshop in question was taken to mean that those entering the bookshop were already beyond being depraved and corrupted and therefore no effect on the likely audience could properly be adduced. The prosecution appealed to the House of Lords. Lord Wilberforce ${ }^{49}$ alluded to the obvious absurdity of this position. The Act, he said:

"... could never have been intended to except from the legislative protection a large body of citizens merely because, in different degrees, they had previously been exposed, or exposed themselves, to the 'obscene material'."

In assessing the likely effect 'on whom', the courts have also considered a specific category of persons, viz. those persons most likely to see, hear or read it.

The target audience then is "persons who are likely, having regard to all relevant circumstances, to read, see or hear the matter contained or embodied in it." 50 Clearly in the case of material for sale in an adult bookshop prohibiting persons under 18 , the likely audience cannot include the under 18 and so the courts are not considering the effect on this age group of the material before them. Accessibility and availability of the material become at least theoretically key issues in this assessment of target audience. Lord Wilberforce ${ }^{51}$ in Whyte took the view that:

48. Whyte, supra n. 38 , at p. $20 \mathrm{~h}$.

49. Ibid., at p. $19 \mathrm{~g}$.

50. Obscene Publications Act 1959, s. 1.

51. Whyte, supra n. 38 , at p. $19 \mathrm{~g}$. 
"In the case of a general shop, open to all and sundry, and offering all types of books, common sense suggests the conclusion that likely reasons are a proportion of all such persons as normally resort to such shops ..."

Consideration of accessibility and availability are also influenced by the price of the material, following the interpretation of "all relevant circumstances" as per Byrne $\mathrm{J}^{52}$ in $R$. v. Penguin Books. When referring to Lady Chatterley's Lover he said:

" $3 / 6 \mathrm{~d}$ you might think would be putting this book within the grasp of a vast mass of the population. They would nevertheless find them physically within their grasp and therefore find themselves arguably within the definition of 'primary audience'."

However, it is to be noted that in practice this consideration has been lamely applied both in arriving at a decision of 'obscene' and in the restriction of sale. Consider, for example, the availability of 'soft pornography' to the eight year old child. Many High Street newsagents display this material traditionally on the top shelf although there is still nothing in law requiring them to do so. Soft porn magazines are stocked in such quantities today that they take up two shelves and in the smaller newsagent these top two shelves may well be at shoulder height of the eight year old. In this case children are very much drawn into the pool of the likely audience and this would surely make such magazines a suitable case for prosecution.

Similarly in a family bookstore, such as Dillons, it is to be expected that the family and, by definition, children are the target audience, situated as this chain store is in the High Street shopping malls. And yet this bookshop still stocks copies of $f$ uliette ${ }^{53}$ and $A$ merican Psycho ${ }^{54}$ at a child shoulder height. It cannot be said that younger children are unlikely to be able to afford to purchase these books at $£, 10.95$ and $£ 8.95$ respectively.

\section{iv. Taking into consideration any defence which may be raised} a. Section 4: public good.

If there are not enough obstacles to prosecution then this section provides the author or the maker with a defence. Section 4 entitles the author/publisher to adduce evidence that the article in question, even if considered obscene, is worthy of artistic or literary merit, a contradiction in terms. Section $4^{55}$ states:

"A person shall not be convicted of an offence against section two of the Act,

55. Obscene Publications Act 1959, s. 4. 
and an order for forfeiture shall not be made under the foregoing section, if it is proved that publication of the article in question is justified as being for the public good on the ground that it is in the interests of science, literature, art or learning, or of other objects of general concern."

Here the opinion of experts may be canvassed to affirm or negate this question. It cost the Crown $£ 1,131.17 \mathrm{~s}$. $3 \mathrm{~d}$. to bring the test case $R$. v. Penguin Books Ltd., which involved much expert opinion on the literary merit. Byrne $\mathrm{J}_{2}{ }^{56}$ in the Lady Chatterley trial, in his summing up said:

"You must consider the book as a whole. The mere fact you are shocked and disgusted, the mere fact you hate the sight of the book does not solve the question."

The jury returned a unanimous 'not guilty' verdict. The judge, however, had his say in making no Order as to costs! Section 4 is an important provision, the purpose of which is to defend and protect works of literature where sexual explicitness is quintessential to the narrative as in Lady Chatterley. There are few, if any, cases today where section 4 is used. Potential section 4 cases are dealt with by non-prosecution. $R$. v. Sylverie and Gibson, ${ }^{57}$ known as the "human earrings" case, where human foetus' of three months gestation were freeze dried, made into droplet earrings and put on display in a private art gallery, might have been such a case if the accused had been proceeded against under the Obscene Publications Act, or if their appeal to have the opportunity of such a prosecution had been successful. A Public Good defence was denied by otherwise charging and proceeding against the defendants via the common law offence of outraging public decency.

\section{b. Ejusdem generis}

Defenders of pornography frequently argue that the material has a social value in preventing excesses of behaviour and in providing a sexual outlet for men. In the 'Bens Books' trial the defence put forward the argument that pornography was for the public good because it had a therapeutic value.

Counsel for defence: This is a picture of a female in chains, tied up, and a naked man pointing a sword at the woman's genitals.

Dr. Richards: This is for the public good because it produces a masturbatory situation. I would certainly prescribe it for a patient.

Counsel: Picture of a naked man with a cat of ninetails striking a woman on her genitals.

56. Cited in Geoffrey Robertson, Obscenity, supra n. 23, at p. 41.

57. R. v. Gibson and Another [1990] Crim.L.R. 738; [1991] 91 Cr. App. R. 341. 
Dr. Richards: This can stimulate a man. It has great therapeutic value.

Counsel: Girl, with distress in her face, arms manacled, and has cuts, she is tied up. A man with a bayonet is inflicting cuts.

Dr. Richards: I have known patients who could benefit by masturbating on this. ${ }^{58}$

In $R$. v. Staniforth and $R$. v. fordan ${ }^{58}$ the defence sought to rely on section 4 and submitted evidence of the medically therapeutic value of obscene materials. The case of Fordan was referred to the House of Lords on a point of law of general public importance:

\begin{abstract}
"whether on the true construction of section 4 of the Obscene Publications Act 1959 expert evidence is admissible in support of the defence under that section to the effect that pornographic material is psychologically beneficial to persons with certain sexual tendencies in that it relieves their sexual tensions and may divert them from anti-social activity."
\end{abstract}

The House of Lords held that to argue that such material was "medically therapeutic" was no defence.

c. So evil so revolting: the aversion defence

It has been argued that the capacity to deprave and corrupt becomes negated when the material depicted is so evil and revolting (an argument, I suggest was probably extended in discussions of $\mathfrak{f}$ uliette to which I return later). Shock and disgust has been deemed both highly relevant and irrelevant. On the one hand, shock and disgust has been held not to solve the question: Byrne J in $R$. v. Penguin Books ${ }^{60}$ and Stable J in the trial of Stanley Kaufman's The Philanderer.$^{61}$ At the same time, the shockability of the material has been crucial to a defence. In $R$. v. Calder and Boyars, ${ }^{62}$ the book, depicting homosexuality, drug-taking and brutal violence, was said not to incite others but rather to act as a deterrent. Salmon LJ, echoing the sentiment of the defence, said:

"The only effect that it would produce in any but a minute lunatic fringe of readers would be horror, revulsion and pity ..."

This argument was extended by Mr. Mortimer for the defence in the $O z$ Magazine trial, $R$. v. Anderson. ${ }^{63}$ Lord Widgery CJ, commenting on the status of

58. Mary Whitehouse, A Most Dangerous Woman?.

59. R. v. Staniforth, R. v. Fordan [1976] 1 All E.R. 714; D.P.P. v. Fordan [1977] A.C. 699.

60. R. v. Penguin Books, supra n. 36.

61. S. Kaufman, The Philanderer; R. v. Martin Secker and Warburg Ltd. [1954] 2 All E.R. 683.

62. $R$. v. Calder and Boyars, supra n. 33, at $984 \mathrm{~b}$.

63. $R$. v. Anderson [1971] 3 All E.R., at p. $1160 \mathrm{~h}(\mathrm{Oz}$ Magazine). 
the aversion argument, said:

". . . in this court Counsel argued, and this court held rightly argued, that the failure of the learned judge to put what one might call the aversion argument was fatal to the retention of the conviction."

The failure of the trial judge to put this aversion 'defence' before the jury in summing up was the major ground for quashing the conviction. It seems that the aversion theory has often been put forward as a 'defence' under section 1 and in addition has been extended as a reason for not prosecuting. Considering the latter, the aversion theory was extended by the Attorney General to the House of Commons in explaining his decision not to prosecute Norman Mailer's The Naked and the Dead. ${ }^{64}$ Again, this is also very likely to have been one of the considerations the present D.P.P. took into consideration when deciding not to prosecute the publishers of Juliette and American Psycho ... "in the light of the defences that may be raised." 65

The aversion test has been described by Lord Denning as a "piece of sophistry". ${ }^{66}$ The pornography industry sales stands as a testimony to the fact that the aversion theory is indeed a piece of sophistry and fails, in my view, since whilst the average reader or reasonable man may be the test for deciding whether something is obscene it is erroneous to apply this same test to determine whether or not the average reader will be averse to the content of a book, film or video. There are plenty of non-average, non-reasonable persons for whom much of this material is bought for pleasure rather than mere idle curiosity and who are certainly not aversed. Moreover, it is precisely the non-average, non-reasonable man who is fast becoming the norm. Geoffrey Robertson, in reference to Mishkin v. New York, ${ }^{67}$ shows how the U.S. Supreme Court pointed to the inherent fallacy of this argument, as per Brennan J:

"where the material is designed for and purely disseminated to a clearlydefined sexual group, rather than the public at large, the prurient appeal requirement of the Roth test is satisfied if the dominant theme of the material taken as a whole appeals to the prurient interest in sex of members of that group."

\section{$v$. Beyond the fantasy debate}

The nature and content of the material available has changed since 1977. We are well beyond the fantasy debate. We are beyond depictions of heterosexual

64. N. Mailer, The Naked and the Dead cited in Robertson, Obscenity, supra n. 23.

65. Private correspondence dated 6th March 1992.

66. R. v. Commissioner of Police of the Metropolis, ex parte Blackbum [1973] 2 W.L.R. 43, at p. 48.

67. Mishkin v. New York 383 U.S. 502 (1966), cited in Robertson, Obscenity, at p. 54, supra n. 23. 
intercourse in explicitness which arouses. The material readily available in 1993 depicts imitatory violence, real violence, torture and assault in a context which some find sexually arousing. ${ }^{68} \mathrm{We}$ are witnessing violent crimes on women and children on film which may result for some recipients in orgiastic relief and for others in the desire to imitate and to go beyond the realm of fantasy. The effect of such material shifts, as does the meaning of deprave and corrupt. Whatever case law has decided, pornography is harmful and does lead to violence against women and children. The law still clings to the view that the test of obscenity is subjective and relative and not objective thereby failing to address the harm of pornography subsumed within it. Meanwhile, as the anti-censorship lobby musters its forces, Dworkin $^{69}$ contends:

"Some women must die during the course of the debate you would like us to have."

Difficult to quantify, difficult to measure, nevertheless pornography has a quintessential responsibility for sexual violence against women. Women and children are harmed in and because of the pornography, ${ }^{70}$ which continues to pour in from other countries masquerading under the 'freedom of trade' banner from the European Community.

The trouble with the Obscene Publications Act is that it is drafted with the object of regulating matters of morality, sexuality, prurient and lascivious conduct otherwise known as obscenity and not with the object of regulating the kind of graphic depictions of extreme violence and torture. The 'deprave and corrupt' test envisaged was one which would be capable of drawing a distinction between a work of literary merit and works of smut, a distinction articulated by Stable J ${ }^{71}$ when summing up in the trial of Stanley Kaufman's The Philanderer:

\begin{abstract}
"I do not suppose there is a decent man or woman in this court who does not wholeheartedly believe that pornography, filthy books, ought to be stamped out and suppressed . . . but in our desire for a healthy society, if we drive the criminal law too far, further than it ought to go, is there not a risk that there will be a revolt, a demand for change in the law, and that the pendulum may swing too far the other way and allow to creep in things that at the moment we can exclude and keep out?"
\end{abstract}

Yet the test of obscenity is assessed not on the intrinsic nature of the material (so as to avoid drawing lines which are considered by some impossible to draw), but on

68. C. Itzin (ed.), Pornography: Women Violence and Civil Liberties (Part Three).

69. A. Dworkin in a speech televised for Channel 4, broadcast 6th November 1991.

70. C. Itzin (ed.), supra n. 68.

71. $R$, v. Mariin Secker and Warburg, supra n. 61, at p. 688e. 
the subjective assessment of the likely effect of such material. Since Stable J's deliberations the material which masquerades under the banner of pornography has not merely widened from smut including explicit sex and nudity, but changed, to include the sadistic torture and killing of, and violence against, women and children, where the formula depends on a lethal conflation of violence and sex.

There should be a reformulation of the object of concern, wherein not only an objective assessment of the material based on harm should be made but the purpose of the publication should also be a consideration; as per Stable J in $R$. v. Secker and Warburg: ${ }^{72}$

"You have to consider whether the author was pursuing an honest purpose ...";

and Lord Pearson in Whyte: ${ }^{73}$

"The question whether an article is obscene depends not only on its inherent character but also on what is being or is to be done with it."

Alas for the written word, which in the case of fuliette describes in detail the dismemberment of women and hideous torture of children. American Psycho similarly glorifies and luxuriates in the horrific killing of women. Such books, the D.P.P. has decided, are unlikely to result in a conviction on the ground of the likely defences that may be raised. What defence is there to raise? And if there is a defence, and the law has facilitated one, the law promotes the intrinsic harm contained in these books.

What these decisions raise is first the question of what, indeed if anything in the written word, would be considered prosecutable. Secondly, they highlight a major lacuna in current legislation respecting the protection of children. Whilst the possession of an indecent photograph of a child is a criminal offence, ${ }^{74}$ it is apparent that any act of murder, torture or sexual crime recorded and detailed in the written word is no offence at all. On the contrary, such crimes in print are protected.

\section{vi. Law reform}

Since the setting up of the Crown Prosecution Service in 1985 the prosecutions under section 2 of the Obscene Publications Act 1959 have actually declined from 583 in 1984, to 174 in 1990 (see Tables 1 and 2).

72. Ibid., at p. 688c.

73. Whyte, supra n. 38 , at p. $18 \mathrm{~g}$.

74. Criminal Fustice Act 1988, s. 160. 
THE DENNING LAW JOURNAL

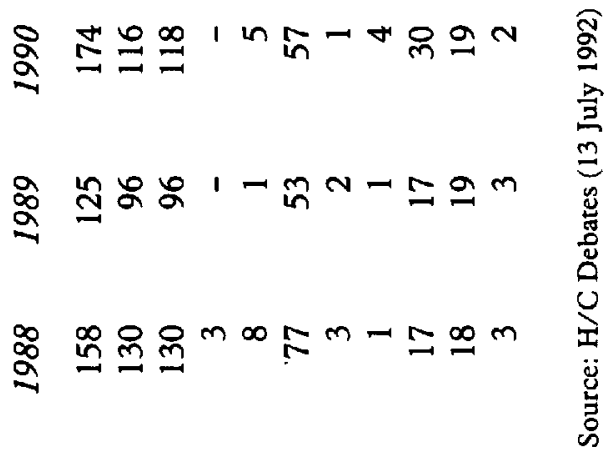

응ํำ

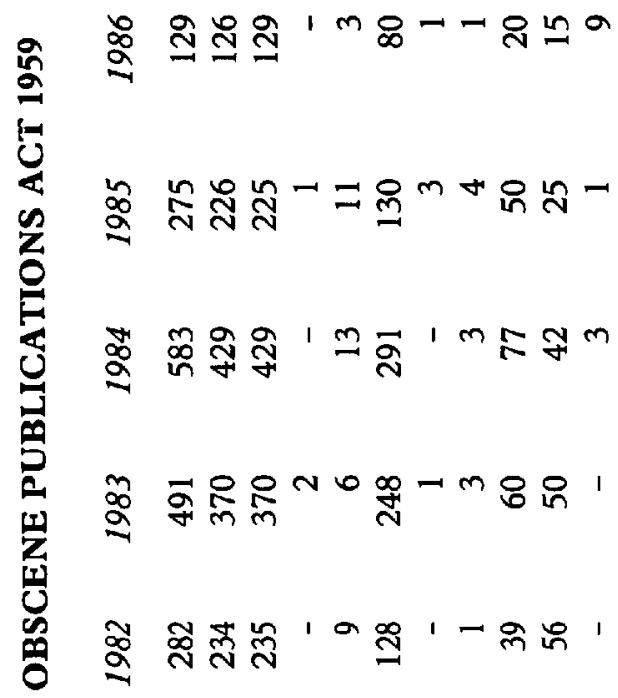

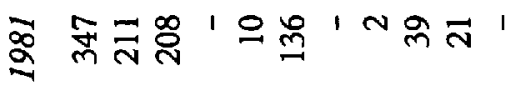

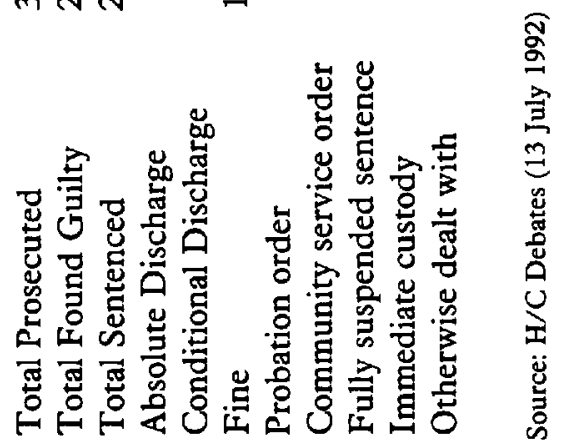


Moreover existing penalties are ineffective, as Lawton $\mathrm{LJ}$ in $R$. v. Holloway ${ }^{75}$ conceded:

"Experience has shown ... that fining these pornographers does not discourage them. Fines merely become an expense of the trade and are passed on to purchasers of the pornographic matter, so that prices go up and sales go on ..."

So like shops' policy on theft, where the consumer pays for losses incurred by shoplifting, the pornography customer pays in price increases for fines incurred by the pornography industry in the advent of a court case.

These recent decisions not to prosecute have understandably refuelled concern over the complete ineffectiveness and insurmountable difficulties with obscenity legislation in controlling and regulating pornography.

Recent efforts to reform the law in respect of pornography here and in America have straddled five positions. First, there have been developments in the US focusing on the harm done to those in the making of pornography. ${ }^{76}$ In 1983 Andrea Dworkin and Catherine Mackinnon drafted an amendment to the Human Rights Ordinance of the City of Minneapolis. ${ }^{77}$ Their objective was to deal with pornography under city civil rights legislation as discrimination against women. The Supreme Court affirmed the Court of Appeal's decision to invalidate the amendment.

In Canada attempts to introduce anti-porn legislation have applied as the appropriate test the community standard of tolerance, and more recently have focused on the harm. ${ }^{78}$

Secondly, there are also some who believe that the 'deprave and corrupt' test should be reformulated, that pornography causes harm and that the tendency to deprave and corrupt should be taken as given where harm is demonstrated.

Thirdly, Parliament has recently turned its attention to reform of the law although the direction of the reform, which it is agreed is much needed, is as yet unclear. On 2nd July 1992, Ms Liz Lynne, a passionate believer in freedom of speech, asked for an adjournment debate on pornography: "The public has been led to believe that our obscenity laws are strong. In fact they are a mess ... the law on books is useless." 79

75. $R$. v. Holloway, supra n. 43.

76. New York v. Ferber 458 (U.S.) 7471025 Ct. 33481982 U.S. LEXIS.

77. Minneapolis City Council Code of Ordinances Relating to Civil Rights, subpara. (gg) to s. 139, 20. See also C. Spaulding, "Anti-Pornography Laws as a Claim for Equal Respect: Feminism, Liberalism and Community", (1989-90) Berkeley Women's Law fo., Vols. 3-4, p. 128. Amendment invalidated in Hudnut, Mayor of City of Indianapolis, Indiana, et. al. v. American Booksellers Assn. Inc. et al. 475 U.S. 109106 5. Ct. 1172 (1986).

78. See Attorney-General (Canada) Report of the Special Committee on Pornography and Prostitution in Canada, Vols. I. and II, Canadian Government Publishing Centre.

79. Hansard, Ms Lynne, 2 July 1992, 1061-1063, at p. 1062. 
On 9 July 1992, Mr. Michael Jack for the Home Office responded, ${ }^{80}$ gingerly conceding: "We believe that there is room for reform of the Act". Mr. Jack has suggested that a possible revision could include the 'reasonable person' standard "a work's offensiveness to a reasonable person" he said:

"The suggestion that we will be obliged to accept supposedly lax continental standards in relation to pornography is simply misplaced." 82

However Parliament at present seems decided that this is a matter for private members and not for Government:

"This is an area for private member initiative." 83

It is to be noted with consternation that earlier private members Bills ${ }^{84}$ were driven into the sand due to lack of time. Professor Stephen Cretney in 1990 outlined ${ }^{85}$ the pros and cons of the process of prikate members Bills as an instrument of law reform:

"Legislation on obscenity is by tradition left to private members and the Government are reluctant - rightly, I believe - to set that tradition aside." 86

Fourthly, it has been proposed that the sale of such material should be restricted and, like films, subject to certification. This certainly must be part of the law reform endeavour. To permit the sale of 7 uliette and American Psycho at a local family bookstall to all and sundry is deeply worrying.

Fifthly, another alternative proposed by journalist Moyra Bremner is "that we replace the Obscene Publications Act with human rights legislation, making it illegal to sell or distribute material which promotes sexual violence and degradation towards anyone of any race, sex, age or social group. So emphasising the real life harm done by pornography." 87

\section{Conclusion}

Pornography is a very vile statement about women. It is a metaphor for the

80. Hansard, Michael Jack, 9 July 1992, 682-689, at p. 687.

81. Ibid., p. 688.

82. Ibid., p. 686.

83. Hansard, 30 June 1992, p. 523.

84. Previous Private Members Bills have failed: see Indecent Displays, Newspapers and Workplaces Bill 1989; Location of Pornographic Material Bill 1989.

85. S. Cretney, "The Forfeiture Act 1982: the Private Members' Bill as an Instrument of Law Reform", Oxford fo. of Legal Studies, Vol. 10, No. 3, pp. 289-306.

86. Official Rep., 15 December 1989, Vol. 153, 1372.

87. Moyra Bremner: Briefing document circulated to M.P.s in June 1992. 
degraded position of women in society. We live in a society where our bodies are increasingly encoded with pornographic meaning, and the general sexualisation of popular culture has resulted in a widespread "acceptance that soft pornographic images may be publicly displayed." 88

The need for law reform in this area has never been more urgent. There is a crisis of confidence amongst police officers, lawyers and the judiciary who feel that the legislation in this area is hopelessly out of touch with public opinion and impotent in its ability to deal with the growing and pernicious manufacture, sale and distribution of this material in all its forms whether book, film, television, cable and other telecommunications. ${ }^{89}$

Any relevance of the subjective test is now defunct as the material in question becomes increasingly focused on actual violence, and on actual crimes committed on film and detailed in print. It can no longer be held to be a moral individual question when harm is being inflicted on recipients and supported, condoned and encouraged. The power of the D.P.P. to decide in these cases to ensure uniformity and consistency has instead been seen to usurp the jury's decision and must be incompatible where the subjective test is relied upon. A decision which relies on popular hunches and popular wisdom concerning what a particular jury, if in possession of certain facts, might decide is pure guesswork.

The recent non-prosecution of American Psycho and $f u l i e t t e$, to name only two of a recent spate of books published detailing similar gruesome narratives, leaves booksellers to sell these books without restriction, regulation or even guidance on the adoption of a top-shelf policy.

A very dangerous situation ferments when men - our fathers, our husbands, our sons and our lovers - are reading this material and are, as I have argued earlier, learning to assimilate pornographic scenarios, which become conflated with male sexual desires and pleasure.

How can any of us remain silent when our children, our sons, may imitate the behaviour, and our daughters may be terrorised, traumatised and abused as a result of male imitation of the matters between such pages and on celluloid? The absence of effective law is symbolically ratifying the harm.

What is needed is a recognition of the harm of this material and an objective test by which to assess it. Without workable legislation in place it will be difficult to resist the threat from Europe where the Court of Justice of the European Community is deciding on matters of free movement of goods wherein already decisions have reflected that pornographic material is just like any other marketable commodity. Similarly, privacy arguments continue to be invoked to defend the choice of those to read and view what they like within the home.

88. D. Cameron and E. Frazer, The Lust to Kill, p. 45.

89. F. Coleman and S. McMurtrie, "Too Hot to Handle", N.L.f., 8 January 1993. 
THE DENNING LAW JOURNAL

\section{Acknowledgment}

Thank you to the Pornography and Violence Research Trust, London, for financially supporting this work as part of a larger study on Pornography. 